\title{
Sciendo
}

DOI: 10.2478/pesd-2019-0005

PESD, VOL. 13, no. 1, 2019

\section{SOIL FERTILITY ASSESSMENT OF AN HIGH NATURAL VALUE ELIGIBLE AREA IN SOUTH-EASTERN TRANSYLVANIA}

\author{
Monica Dumitrașcu ${ }^{1}$, Mihaela Lungu ${ }^{2}$, Sorin Liviu Ștefănescu ${ }^{3}$, \\ Victoria Mocanu ${ }^{4}$, Gabi Mirela Matei, Rodica Lazăr
}

Key words: HNV area, soil quality, soil survey.

\begin{abstract}
As low-input environmentally friendly agricultural practices are currently associated with the delivery of a wide range of public goods and socioeconomic benefits, the strategy of European Union in mitigating climate change effects, protecting environment and ensuring public health has, among others, focused around preserving the High Natural Value (HNV) areas. About a quarter of the land in Romania is potentially covered by HNV farming and eligible for associated support payments, mostly along the chain of the Carpathian Mountains. Since soil systematic data on HNV area are scarce, recent research developments currently undertake to build up a first national HNV soil data base.

Soil fertility state in a HNV payment eligible area of south-eastern Transylvania was studied in seven in-depth dug profiles and seven additional shallow dug profiles. Soil samples were taken by genetic horizons as well as agrochemical samples from the upper soil layers $(0-20 \mathrm{~cm})$. Physical, chemical, and microbiological analyses revealed that the studied soils have a medium clayey loamy texture, good fertility and are subject to an adequate HNV management in the area, as the analytical values mostly range in favorable intervals for plant growth and nutrition. Thus, soil reaction is moderately acid up to slightly alkaline in the presence of carbonates, the soil organic matter, generally well mineralized, reaches fair levels and the high and very high cation exchange capacity ensure good conditions for plants growth and nutrition whilst nitrogen and potassium supply is adequate. Phosphorus is the only element in short supply - a situation often encountered in Romania unfertilized soils. Soil bulk density and total porosity are also favorable for root growth and spreading and plant nutrition. Microorganisms' activity is diverse and is also adequate for plant nutrition.
\end{abstract}

1 National Research and Development Institute for Soil Science, Agrochemistry and Environment - ICPA Bucharest, ${ }^{1}$ monica.dumitrascu@icpa.ro; ${ }^{2}$ mihaela.lungu@icpa.ro; ${ }^{3}$ sorin.stefanescu@icpa.ro; ${ }^{4}$ victoria.mocanu@icpa.ro 


\section{Introduction}

Facing a growing public recognition of the need for a better natural resources sustainable management to safeguard the environment and cope with recent societal challenges (climate change, soil quality, fresh water provision, food safety, livability of rural areas etc.), within the last decades a significant shift of the EU agricultural and rural development policies on financial compensation for certain agri-environment practices has been launched. Substantial support has been directed to High Nature Value (HNV) farming, an agricultural production system that provides recognized environmental public goods and maintains a wide range of semi-natural habitats or less natural but still important habitats for biodiversity in many of the European Member States. Most of the HNV farming systems are found in a variety of different agronomic, economic, social and environmental contexts, but are generally concentrated in the more marginal areas of rural Europe where baseline agricultural productivity is most constrained by factors such as poor soils, steep slopes, high altitude, low rainfall, rocky outcrops, etc. and where there is least potential to intensify production (Redman, 2014).

Since 2006, the EU has adopted HNV farming as one of three priorities for Axis 2 of Rural Development Programs (RDPs) and simultaneously, HNV farming and forestry indicators were established as part of the Common Monitoring and Evaluation Framework (CMEF) for RDPs. Member States were required to devise a system of "impact indicators" for measuring tendencies in the extent and condition of HNV farmland and forestry and should also establish "results indicators" for assessing the extent of land under successful land management contributing to biodiversity and high nature value farming/forestry as well as avoidance of marginalization and land abandonment (Beaufoy and Jones, 2012).

In Romania, the national decision makers and planners have set up an ambitious scheme for supporting HNV farming through agri-environment payments within the national RDP in-between 2007-2013 as well as for the period 2014-2020 as the country holds a large proportion of the HNV farmland with almost 5 mil ha (roughly $30 \%$ of the national total Utilized Agricultural Area) eligible to receive support (MADR, 2017).

But the existing information on soils' level of fertility in the HNV eligible area is scarce. Reliable soil data and monitoring might show us when soils quality decreases to a level harmful to soil functions, food security and human health. Soil monitoring is an important instrument counting the level of land degradation. With regard to an actual proposal for a European wide soil monitoring network to provide an information and data tool for scientists and decision makers (Makenshin, 2016), a recent research project in Romania started 
to build-up the first national HNV soil data base and to design a proper HNV soil monitoring system (Lungu et al., 2017).

In the first stage of building-up the HNV soil data base, afield investigation was carried out in the HNV eligible area of south-eastern Transylvania, in the Târnava Mare Natura 2000 site. Târnava Mare area (hosting the valuable cultural landscape of the Saxon Villages), was declared a Natura 2000 site under the Birds and Habitats Directives in 2008. The area consists of undulating terrain with altitudes from 300 to $700 \mathrm{~m}$ above sea level under a sub continentaltemperate climate (Loos et al., 2015), has an outstanding grassland diversity (Akeroyd and Page, 2011), includes an astonishing 8 EU Habitats Directive Annex 1 grassland habitats (of which 4 are priority habitats) and benefits of the strong and successful involvement of ADEPT Foundation, a local initiative, actively combining EU support measures and commercial development measures. In contrast to much of Europe, the selected area represents a functioning historic landscape, with the fauna, flora and complement of soil micro-organisms of an intact ancient ecosystem, in which extensive wildflower meadows and traditional pastures retain their role in agriculture. Such areas are rare in lowland Europe, and are therefore extremely valuable for conservation research and interpretation. Farming is predominantly carried out in small, semisubsistence farms (ADEPT, 2010). In the case of Southern Transylvania, conservation policies are targeting the individual small farmer to influence their behavior primarily not to abandon the area and continue working the land in a traditional manner. These policies lie at cross-roads between rural development and biodiversity conservation, leading to a high diversity of institutional arrangements responsible with the implementation, monitoring and coordination (Dinu, 2012).

\section{Material and methods}

Soil sampling was done in 2017 and 2018, after hay harvesting in the habitat type 6210* ,Semi-natural dry grasslands and scrubland facies on calcareous substrates (Festuco-Brometalia) with important orchid sites" of the Târnava Mare pSCI (priority habitat according to Annex I of Habitats Directive) Soil disturbed and undisturbed samples were taken at different levels from the soil profile, according to the field identified soil genetic layers. Disturbed samples were used for laboratory measurements according to established methodology and specific standards: structure, organic carbon content, $\mathrm{pH}$, content of available phosphorus and potassium, total nitrogen. The undisturbed samples were taken in rings of $200 \mathrm{~cm}^{3}$ and used for measurement of bulk density (BD), penetration resistance (PR), total porosity (TP), soil moisture (SM), compaction index (CI), 
saturated water hydraulic conductivity $(\mathrm{HC})$, and degree of soil compactness (SC).

Cation exchange properties were determined in samples with $\mathrm{pH}$ lower than 7.

Salinization intensity was assessed by the total soluble salts content in 1:5 aqueous extract.

The microbiological analyses were performed in the samples taken from the upper soil horizons targeting: heterotroph bacteria number determined by the soil dilutions - suspensions method through dispersion on Topping medium; microscopic fungi number determined by soil dilution - suspensions method on Czapek nutrition medium (Papacostea, 1976); soil respiration potential level assessed by the respiration method induced by substratum addition (SIR).

Taxonomic analyses were carried out based on cultural, morphologic and/or physiologic characteristics, according to specific catalogues for determining bacteria (Bergey, 1994) and fungi (Domsch \& Gams, 1972, Watanabe, 2002 and Samson \&van Reenen-Hoestra, 1988).

The chromatograms allow getting information regarding soil biologic quality through analytic segregation and formation of images whose uniformity, form, measure, color, and structure model indicates soil health degree, vitality, fertility, biotic activity intensity, soil conditions, organic matter complexity degree, and stable humus presence.

\section{Results and discussions}

Most of the soils in the area have a medium clayey loamy texture with a clay content $(<0,002 \mathrm{~mm})$ ranging from $30-40 \%$, with slight increases of the clay content in random layers of the profiles and slightly lower contents of the clay (loamy texture) in some layers of the soils of the north-eastern part of the investigated area (Table1).

Regarding the values of the soil physical properties (Dumitru et al. 2009), the average soil bulk density in the first (upper) soil layer is $1.3 \mathrm{~g} / \mathrm{cm}^{3}$ (ranging in different sampled soil profiles from 0.9 to $1.6 \mathrm{~g} / \mathrm{cm}^{3}$ ) and the average soil total porosity is $49.8 \% \mathrm{v} / \mathrm{v}$ (ranging in different sampled soil profiles from 41.7 to $65.3 \% \mathrm{v} / \mathrm{v})$. In the second top-down layer no critical changes of the physical properties occur: the average soil bulk density is $1.4 \mathrm{~g} / \mathrm{cm}^{3}$ (ranging in different sampled soil profiles from 1.2 to $1.5 \mathrm{~g} / \mathrm{cm}^{3}$ ) and the average soil total porosity is $48.4 \% \mathrm{v} / \mathrm{v}$ (ranging in sampled soil profiles from 43.1 to $55.9 \% \mathrm{v} / \mathrm{v}$ ). The average values of penetration resistance are close to the medium levels (52 $\mathrm{kgf} / \mathrm{cm}^{2}$ in the upper soil layer and $58.4 \mathrm{kgf} / \mathrm{cm}^{2}$ in the second top-down layer) while the average values of the contraction index $(0,0074$ in both soil depths) indicate a non-susceptibility for soil cracking. The average values of the 
saturated water hydraulic conductivity $(12.5 \mathrm{~mm} / \mathrm{h}$ in the upper soil layer and $11.6 \mathrm{~mm} / \mathrm{h}$ in the second top-down layer) show relatively high soil permeability and a good level of soil internal water drainage. In correlation with the analyzed soil texture, as most of the values of soil bulk density and total porosity have a medium level and the calculated average degree of soil compactness reveals low values $(-0.60519 \% \mathrm{v} / \mathrm{v}$ in the upper soil layer and $7.3469 \% \mathrm{v} / \mathrm{v}$ in the second topdown layer), the absence or no more than a slightly compactness of the sampled soils signal an overall fair HNV soil conservation management in the area.

Tab. 1 Statistical parameters of the soil samples physical properties

\begin{tabular}{|c|c|c|c|c|c|c|c|c|}
\hline $\begin{array}{r}\text { Properties } \\
\text { Depth } \\
(\mathrm{cm})\end{array}$ & $\begin{array}{c}\text { Clay } \\
<0,002 \\
\mathrm{~mm} \\
\%\end{array}$ & $\begin{array}{c}\mathrm{BD} \\
\mathrm{g} / \mathrm{cm}^{3}\end{array}$ & $\begin{array}{c}\mathrm{PR} \\
\mathrm{kgf} / \mathrm{cm}^{2}\end{array}$ & $\begin{array}{c}\mathrm{TP} \\
\% \mathrm{v} / \mathrm{v}\end{array}$ & $\begin{array}{c}\mathrm{SM} \\
\% \mathrm{~g} / \mathrm{g}\end{array}$ & CI & $\begin{array}{c}\mathrm{HC} \\
\mathrm{mm} / \mathrm{h}\end{array}$ & $\begin{array}{c}\mathrm{SC} \\
\% \mathrm{v} / \mathrm{v}\end{array}$ \\
\hline parameters & $0-15 / 25$ & \multicolumn{6}{|c|}{$5-25$} & $0-20$ \\
\hline $\mathrm{n}$ & 20 & 10 & 10 & 10 & 10 & 10 & 10 & 8 \\
\hline$\overline{\mathrm{x}}$ & 32.6 & 1.3 & 52 & 49.8 & 20.0 & 0.0074 & 12.5 & -0.61 \\
\hline $\mathrm{x}_{\min }$ & 20.1 & 0.9 & 23 & 41.7 & 14.6 & 0.0022 & 2.6 & -28.29 \\
\hline $\mathrm{X}_{\max }$ & 43.8 & 1.6 & 79 & 65.3 & 27.2 & 0.0114 & 26.7 & 18.18 \\
\hline$\sigma$ & 6.4 & 0.2 & 14 & 7.2 & 4.3 & 0.0024 & 7.7 & 15.26 \\
\hline \multirow[t]{2}{*}{$\mathrm{cv}, \%$} & 19.5 & 14.4 & 27.5 & 14.5 & 21.4 & 32.9 & 61.8 & -2.521 .45 \\
\hline & $\begin{array}{l}20 / 25- \\
30-50\end{array}$ & \multicolumn{6}{|c|}{$20-50$} & $20-40$ \\
\hline $\mathrm{n}$ & 9 & 9 & 9 & 9 & 9 & 9 & 9 & 7 \\
\hline$\overline{\mathrm{x}}$ & 36.4 & 1.4 & 58.4 & 48.4 & 18.4 & 0.0074 & 11.6 & 7.35 \\
\hline$x_{\min }$ & 33.2 & 1.2 & 36.0 & 43.1 & 14.4 & 0.0030 & 0.6 & -8.95 \\
\hline $\mathrm{X}_{\max }$ & 41.5 & 1.5 & 85.0 & 55.9 & 23.1 & 0.0113 & 47.3 & 16.74 \\
\hline$\sigma$ & 2.8 & 0.1 & 14.1 & 3.9 & 2.9 & 0.0029 & 14.1 & 8.68 \\
\hline $\mathrm{cv}, \%$ & 7.7 & 7.6 & 24.2 & 8.1 & 15.8 & 39.0 & 121.1 & 118.20 \\
\hline
\end{tabular}

Soil reaction (Table 2) varies on a wide range, from $5.78 \mathrm{pH}$ value to 8.24 , covering the moderately acid - slightly alkaline domains (Florea et al., 1987). Values of the slightly acid domain are registered in the Angofa, Saschiz 2, and Apold 2 profiles. In the Apold 1, Saschiz 1, and Saschiz 3 profiles the values generally belong to the slightly alkaline domain while the Saschiz 4 reaction is neutral. Agrochemical samples reaction is the same with that determined in the upper profile layers. The values are generally favorable for plants growth. According to Vasu (1986) 4.40-6.00 is the interval of characteristic $\mathrm{pH}$ values for constant grassland soils. The higher values are consistent with the carbonates presence in the soil profile.

Both the samples from profile horizons and the agrochemical ones have high and very high organic matter (humus) contents, except for the Saschiz 3 profile where the values are low - average. The assessment was done taking into account the soil structure (Florea et al., 1987). All the values range in the domain 
of frequently encountered values in mountainous grass lands and meadows soils (3-12\%, 12-40\%; Vasu, 1986). The $\mathrm{C} / \mathrm{N}$ ratios, with $4.5-31.4$ values, generally describe rather well humified organic matter content. Exceptions are registered in the Saschiz 1 upper horizon and in the Angofa and Saschiz 4 agrochemical samples. The high values in these samples suggest the existence of some organic matter remains in process of humification.

Tab. 2 Statistical parameters of soil chemical properties

\begin{tabular}{|c|c|c|c|c|c|c|c|}
\hline $\begin{array}{l}\text { Properties } \\
\text { Statistical } \\
\text { parameters }\end{array}$ & $\mathrm{pH}$ & $\begin{array}{c}\text { Humus } \\
\%\end{array}$ & $\begin{array}{l}\mathrm{Nt} \\
\%\end{array}$ & $\mathrm{C} / \mathrm{N}$ & $\begin{array}{l}\mathrm{N}-\mathrm{NO}_{3} \\
\mathrm{mg} / \mathrm{kg}\end{array}$ & $\begin{array}{c}\mathrm{P}_{\mathrm{AL}} \\
\mathrm{mg} / \mathrm{kg}\end{array}$ & $\underset{\mathrm{mg} / \mathrm{kg}}{\mathrm{K}_{\mathrm{AL}}}$ \\
\hline \multicolumn{8}{|c|}{$0-20 / 25 \mathrm{~cm}$} \\
\hline $\mathrm{n}$ & 19 & 19 & 19 & 19 & 19 & 19 & 19 \\
\hline$\overline{\mathrm{x}}$ & 7.15 & 5.74 & 0.243 & 16.6 & 16 & 10 & 268 \\
\hline $\mathrm{X}_{\min }$ & 5.78 & 1.98 & 0.107 & 11.4 & 5 & 1 & 117 \\
\hline $\mathrm{X}_{\max }$ & 8.24 & 13.80 & 0.562 & 31.4 & 60 & 16 & 467 \\
\hline$\sigma$ & 0.88 & 3.10 & 0.118 & 6.4 & 14 & 6 & 92 \\
\hline $\mathrm{cv}, \%$ & 12.3 & 53.9 & 48.5 & 38.8 & 91.8 & 60.2 & 34.1 \\
\hline \multicolumn{8}{|c|}{$15-40 / 50 \mathrm{~cm}$} \\
\hline $\mathrm{n}$ & 11 & 11 & 11 & 11 & 11 & 11 & 11 \\
\hline$\overline{\mathrm{x}}$ & 7.41 & 4.29 & 0.225 & 12.7 & 8 & 3 & 152 \\
\hline $\mathrm{X}_{\min }$ & 6.32 & 2.16 & 0.103 & 10.1 & 4 & 1 & 87 \\
\hline $\mathrm{X}_{\max }$ & 8.31 & 11.76 & 0.536 & 15.0 & 16 & 7 & 249 \\
\hline$\sigma$ & 0.82 & 2.84 & 0.124 & 1.8 & 3 & 2 & 49 \\
\hline $\mathrm{cv}, \%$ & 11.0 & 66.0 & 55.1 & 14.4 & 42.6 & 75.4 & 32.2 \\
\hline
\end{tabular}

Nitrogen contents are also normal for grass lands and meadows soils and balance well the organic matter contents as the $\mathrm{C} / \mathrm{N}$ ratio also suggest. There are some exceptions, previously mentioned.

Nitrate contents are generally low (Florea et al., 1987) and align to the usual values range in such soils (Vasu et al., 1986). Some slightly higher values occur in the upper horizon of the Saschiz 1 profile, in its corresponding surface agrochemical sample, and in the first horizon of the Apold 2 profile, which we attribute to old animal dejections (the pastured were not grazed at the moment of soil sampling) and are far from raising any contamination concerns.

Mobile phosphorus contents soluble in ammonium acetate lactate solution at pH 3.7 are low and very low (Florea et al., 1987), an often encountered situation in Romania soils. On the contrary, mobile potassium contents soluble in the same extracting solution are average, high, and very high (Florea et al., 1987); low values are registered in only few samples collected from deep horizons.

The actual cation exchange capacity $(\mathrm{T}=\mathrm{BS}+\mathrm{Ah}$, Table 3$)$ in the Angofa profile is high in the upper two horizons and average at $40-70 \mathrm{~cm}$ depth, 
exchange bases sum (BS) is on the average - high threshold in the upper two horizons and average at $40-70 \mathrm{~cm}$ depth, and the hydrolytic acidity is average in the upper two horizons and low at the 40-70 $\mathrm{cm}$ depth. According to the base saturation degree the soil is below-mesobasic.

Tab. 3 Statistical parameters of the soil cation exchange properties

\begin{tabular}{|c|c|c|c|c|}
\hline Properties & BS & $\mathrm{Ah}$ & $\mathrm{T}=\mathrm{BS}+\mathrm{AH}$ & \multirow{2}{*}{$\begin{array}{c}\mathrm{V}_{\mathrm{Ah}} \\
\% \text { of T }\end{array}$} \\
\hline parameters & \multicolumn{3}{|c|}{$\mathrm{me} / 100 \mathrm{~g}$ soil } & \\
\hline \multicolumn{5}{|c|}{$0-20 \mathrm{~cm}$} \\
\hline $\mathrm{n}$ & 8 & 8 & 8 & 8 \\
\hline$\overline{\mathrm{x}}$ & 29.72 & 5.15 & 34.87 & 85.2 \\
\hline $\mathrm{x}_{\min }$ & 25.74 & 3.48 & 30.31 & 81.2 \\
\hline $\mathrm{x}_{\max }$ & 34.84 & 6.40 & 40.51 & 88.6 \\
\hline$\sigma$ & 3.82 & 0.88 & 4.08 & 2.5 \\
\hline $\mathrm{cv}, \%$ & 12.9 & 17.0 & 11.7 & 3.0 \\
\hline \multicolumn{5}{|c|}{$20-40 \mathrm{~cm}$} \\
\hline $\mathrm{n}$ & 4 & 4 & 4 & 4 \\
\hline $\bar{x}$ & 29.48 & 4.18 & 33.66 & 87.54 \\
\hline $\mathrm{x}_{\min }$ & 25.32 & 2.76 & 28.60 & 83.39 \\
\hline $\mathrm{x}_{\max }$ & 33.91 & 5.04 & 38.38 & 90.35 \\
\hline$\sigma$ & 4.53 & 0.99 & 4.90 & 2.95 \\
\hline $\mathrm{cv}, \%$ & 15.4 & 23.6 & 14.6 & 3.4 \\
\hline
\end{tabular}

The correspondent agrochemical samples present a high actual cationic exchange capacity, high exchange bases sum, and average hydrolytic acidity in the $0-10 \mathrm{~cm}$ layer and high in the $10-20 \mathrm{~cm}$ one; the soil is below-mesobasic from the base saturation degree point of view.

In the Saschiz 2 profile the actual cation exchange capacity is very high in the upper two horizons and high on the rest of the profile, exchange bases sum is high in the whole profile, and hydrolytic acidity is average in the upper horizons down to $85 \mathrm{~cm}$ depth and low deeper. According to the base saturation degree the soil is mostly below-mesobasic, except for the last horizon where it's eubasic.

The correspondent agrochemical samples present a very high actual cation exchange capacity, high exchangeable bases sum, and average hydrolytic acidity. The soil is below mesobasic from the base saturation degree point of view.

The actual cation exchange capacity is high in the Apold 2 profile, the exchange base sum is on the average - high threshold, and the hydrolytic acidity is average in the upper horizon and low in the next. According to the base saturation degree the soil is below mesobasic in the upper two horizons. 
The corresponding agrochemical sample presents a high actual cation exchange capacity, high exchange bases sum, and low hydrolytic acidity. The soil is below-mesobasic from the base saturation degree point of view.

The analyzed soil samples are non-salinized because the total soluble salts content is much below the threshold value from which slight soil salinization begins (100 $\mathrm{mg}$ soluble salts/100 $\mathrm{g}$ soil for an average structure).

Microbiological indices interpretation was done by the following criteria:

Number of bacteria:

$<10$ mil./g dry soil low

10-20 mil./g dry soil average

Number of fungi:

$>20 \mathrm{mil}$ / g dry soil high

Soil respiration:

$\begin{array}{ll}<50 \mathrm{mii} / \mathrm{g} \text { dry soil } & \text { low } \\ 50-100 \mathrm{mii} . / \mathrm{g} \text { dry soil } & \text { average } \\ 100-200 \mathrm{mii} . / \mathrm{g} \text { dry soil } & \text { high } \\ >200 \mathrm{mii} / \mathrm{g} \text { sol dry soil } & \text { very high } \\ \text { iration: } & \\ <30 \mathrm{mg} \mathrm{CO} / 100 \mathrm{~g} \text { dry soil } & \text { low activity } \\ 30-80 \mathrm{mg} \mathrm{CO}_{2} / 100 \text { g dry soil } & \text { average activity } \\ >80 \mathrm{mg} \mathrm{CO}_{2} / 100 \mathrm{~g} \text { dry soil } & \text { high activity }\end{array}$

Soil chromatography analysis reveals an increased enzyme activity in Saschiz 2, Angofa, and Apold 1 samples. It increases even much above average in the Saschiz 2 sample. The functional diversity is well highlighted in the Saschiz 2 and Angofa samples. The lowest level of activity and functional diversity is highlighted in the Saschiz 3 and 4 samples. The Apold 2 enzyme activity level is close to the one noticed in the Saschiz 1 sample.

The nutrition supply with the highest level and the highest diversification degree occurs in the Saschiz 2 sample. An increased nutrition supply but poorly diversified occurs in the Saschiz 1 and Apold 2 profiles and a balanced situation between supply and diversification degree is noticed in the Apold 1 sample, closely followed by Saschiz 3 and 4 .

Humification processes are generally intense, colloidal substances are present, the mineral component is very well integrated in the organic material in the Saschiz 2 sample, followed by Apold 1 and Angofa samples. Humification is depressed in the Saschiz 3 and Angofa samples and the colloidal substances presence is lessened.

The proteins content, well organized and complex, is highlighted especially in the Apold 1 and Saschiz 1 and 4 samples. The lowest protein compounds 
structural organization degree is noticed in the Angofa sample soil chromatogram.

Bacteria activity is well highlighted in the Apold 1, Saschiz 1-3, and Angofa samples, and the fungi activity in the Apold 1 and Angofa samples. The bacteria and fungi micro flora edaphic activity is poorly represented in the Saschiz 4 profile.

There is generally a good connection between components, aggregates are present in solution, and mineralization exists in the Apold 1 soil which intensifies in the Saschiz 2 one. The mineralization inclination is much depressed in the Saschiz 3 and 4 samples.

\section{Conclusions}

Some of the investigated soils chemical properties (soil reaction, for example) are significantly different and fit better in the frame of good fertility models as compared to previous results regarding meadow soils in Romania (Vasu, 1986).

Physical, chemical, and microbiological analyses of samples collected from seven in-depth dug profiles and additional shallow dug profiles in a HNV payment eligible area of south-east Transylvania revealed that the studied soils have a medium clayey loamy texture, good fertility and are subject to an adequate HNV management in the area, as the analytical values mostly range in favorable intervals for plant growth and nutrition.

The collected soil analytical data suggest that HNV practices unfolded in the investigated area fairly comply with the soil conservation requirements and must continue as far as land and soil careful administration is concerned in order to meet the society demands for natural resources and their supply.

Aknowledgments: The paper was drawn in the frame of a Nucleu type research project (PN 160701 06), funded by the Ministry of Research and Innovation.

\section{References}

ADEPT Foundation (2010), High Nature Value grasslands. Securing the ecosystem services of European farming post 2013, International conference, September 7-9 2010, Sibiu, Romania. Available at: http://www.fundatiaadept.org/?content=publications. 
Akeroyd J. R., Page N. (2011), Conservation of High Nature Value (HNV) grassland in a farmed landscape in Transylvania, Romania, Contrib. Bot. XLVI, 57-71, available at: http://contributii_botanice.reviste.ubbcluj.ro/materiale/2011/Contrib_Bot_vol_46_ pp_057-071.pdf (Accessed in 20.05.2018).

Bergey $\bar{D}$. H., Holt J. G. (1994), Bergey's Manual of Systematic Bacteriology 9th Ed., Wiliams and Wiliams Eds., Baltimore, USA.

Beaufoy G., Jones Gwen (2012), HNV farming in England and Wales- findings from three local projects, EFNCP, Stapledon Memorial Trust, Wye Valley AONB, European Commission DG Environment. Published by EFNCP, UK. Available at: http://www.efncp.org/download/HNV_Farming_brochure_final.pdf

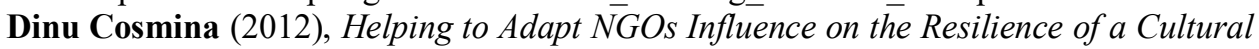
Landscape from Transylvania, Romania (A Comparative Analysis), MSc Thesis, Utrecht University, the Netherlands.

Domsch K. H., Gams W. (1970), Fungi in agricultural soils, T\&A Constable Ltd., Edinburg, London.

Dumitru E., Calciu I., Carabulea V., Canarache A. (2009), Analytical methods used in the Laboratory of soil physics - National Research and Development Institute for soil Science, Agrochemistry and Environment - ICPA, SITECH Publishing House, Craiova, Romania (published in Romanian).

Florea N., Bălăceanu V., Răuță C., Canarache A. (Coord. reds.) (1987), Methodology of pedologic studies elaboration. Part III - Ecopedologic indicators, MA, ASAS, ICPA Bucharest (published in Romanian).

Loos J., Turtureanu P. D., von Wehrden H., Hanspach J., Dorresteijn I., Pál Frink J., Fischer J. (2015), Plant diversity in a changing agricultural landscape mosaic in Southern Transylvania (Romania), Agriculture, Ecosystems and Environment 199: 350-357, available la: http://dx.doi.org/10.1016/j.agee.2014.10.013 (accessed on 20.05.2018).

Lungu Mihaela., Ștefănescu S. L., Dumitrașcu M., (2017), The fertility level of some soils from pastures and meadows located in the eligible High Natural Value area (In Print).

MADR (2017), National Rural Development Program, Version 5, June 30. Available at: http://www.madr.ro/.

Makeschin F., Schröter-Schlaack C., Glante F., Zeyer J., Gorgon J., Ferber U., Villeneuve J., Grimski D., Bartke S. (2016), INSPIRATION Report Concluding 2nd Project Phase: Enriched, Updated and Prioritized Overview of the Transnational Shared State-of-the-art as Input to Develop a Strategic Research Agenda and for a Matchmaking Process. Public version of the Final Version as of 30.10.2016 of Deliverable D3.4 of the HORIZON 2020 Project INSPIRATION. EC Grant agreement no: 642372. UBA, Dessau-Roßlau, Germany.

Matei S. (2011), Determination of soil respiration and microbial biomass, in: Dumitru M., Manea A. (Coord.) (2011), chemical and microbiological analyses methods (used in the soil monitoring system), SITECH Publishing House, Craiova, p. 283288 (published in Romanian). 
Papacostea P. (1976), Soil Biology, Scientific and Encyclopedic Publishing House, Bucharest.

Redman M. (2014), High Nature Value (HNV) farming profitability. Starting paper prepared for the first Focus Group meeting in Madrid, Spain (12-13 June 2014), EIP- AGRI Focus Group, EC. Available at: https://ec.europa.eu/eip/agriculture/sites/agrieip/files/fg7_hnvf_profitability_starting_paper_2014_en.pdf

Samson A. R., Hoekstra R. S. E. (1988), Introduction to food borne fungi, Ed.CBS Netherland.

Vasu Alexandra, Neacşu Marcela, Daniliuc D., 1986, Ecopedologic characterization of representative meadows units from the mountainous area in order to establish the need for improvement technologies measures, Lucr. Şt. ale ICPCP Măgurele Braşov, Vol.IX, Bucharest (published in Romanian).

Watanabe T. (2002), Pictorial Atlas of Soil and Seed Fungi: Morphologies of Cultured Fungi and Key to Species 2nd ed., CRC PRESS, Boca Raton London, New York, Washington D.C., USA. 